\title{
Socio-Cultural Approaches to Tourism: A Research on the "Tourist" Notion of Young Turkish People
}

\author{
Ferika Özer Sari \\ Department of Tourism and Hotel Management, Vocational School, Yaşar University, Izmir, Turkey \\ Email: ferika.ozersari@yasar.edu.tr \\ Received December $23^{\text {rd }}, 2011$; revised January $21^{\text {st }}, 2012$; accepted February $17^{\text {th }}, 2012$
}

\begin{abstract}
Significance of tourism sector in Turkey is constantly expanding. Correspondingly the importance of the economic and socio-cultural impact of tourism also continues to develop. Because tourism draws tourists get into closer contact with the locals it has positive and negative effects on the destination. In general the aim of tourists is satisfying their expectations at the maximum degree during their stay. On the other side locals who live and work in the destination region have a primary role in welcoming them and satisfying the tourists' needs and expectation. Turkish society is particularly well known for many generations as being very hospitable. Current research aims to reveal whether the young Turkish people sustain traditional "Turkish Hospitality" and to see their thoughts about tourists. The field research has been conducted on students of a foundation university located in Izmir and these young people's point of view on tourists has been investigated by face to face interviews. It has been concluded that there is a weakening trend, nevertheless the notion of hospitality remains.
\end{abstract}

Keywords: Tourism Sociology; Tourist; Young Turkish; Traditional Turkish Hospitality; Guest

\section{Introduction}

Tourism industry has a growing importance for Turkey. The destination has been the ninth most visited country in terms of incoming tourists and seventh in terms of tourism revenue worldwide. The incoming tourist numbers has increased to 28.6 million, tripling when compared with 10 years ago. Revenues from tourism have reached 20.8 billion dollars, tripling since 2000, when it had been 7.6 billion dollars (Turkish Ministry of Culture and Tourism, 2011). Tourism, which is of increasing importance day by day to the national economy, has been gaining importance culturally and socially.

Formerly, some of the tourism researchers such as Butler in 1980, Doxey in 1975, Smith in 1989 and De Kadt in 1979 studied the regional tourism activities and the host-guest relationship (Cooper et al., 2008: p. 188). De Kadt suggested three main categories of host-guest contact (Cooper et al., 2008: p. 192): when the guests buy goods and services from the hosts; when the locals and tourists share a facility such as a cafe, a restaurant or a concert hall, etc. and when tourists and locals come together for the main purpose of cultural exchange. The first two types of these communications are come with the generality of unfavourable sides of social contact, whereas the third type of contact is usually thought to be positive (Cooper et al., 2008: p. 193). The relationship between tourists and locals is reviewed in this paper.

\section{Review of Literature}

\section{Relationship between Tourists and Locals}

An important contribution to the studies about the relationship between hosts and guests was made by Doxey in 1975 . This model is also known as "Irridex (Index of Tourist Irritation)" and propounds that there is an evolutionary change in local people's behaviour towards tourists. If we are to measure the level of sensitivity generated by host-guest contact Doxey created below Index (Cooper et al., 2008: p. 195):

- The level of euphoria-excitement and enthusiasm in the beginning stages.

- The level of apathy — what contact is made between locals and tourists is done on a commercial and official basis.

- The level of irritation-tourism industry gets close to contentedness.

- The level of antagonism - the tourist is now perceived as the reason of all sufferings.

- The final level - the social impact has been carried out and the tourists will choose other destinations.

While the tourist-local relationship is a matter of debate, examining the relations between different groups of hosts and tourists is relevant to this paper. Locals' regard and appraisal of and behaviour towards tourists may vary during any of the three main categories of host-guest contact described above. Different groups within the same community may also have different manners and perceptions of communication and interaction with tourists. As there is no possible way to resolve the issues of perception about tourists (in this paper) or to analyse each and every group of tourists, a categorisation of hosts and guests has been determined based on the observations of various other writers below:

Upper Class Locals - as their lifestyles are similar with those of tourists and their educational and cultural levels are high, and most of them can speak the language of tourists. Upper class locals are those who can most easily interact with the tourists (Avc1kurt, 2003: p. 59).

Lower Class Locals - as it is easy for upper class locals to communicate with tourists, so it is hard to do so for this group. Among the reasons for this may be the difference between their life styles, a lack of language skills, a lack of information about 
the countries and cultures of tourists, fear from rich tourists, shyness, belittlement and jealousy (Avc1kurt, 2003: p. 59).

Young People - since younger locals tend to fancy novelty and adventure, meeting with foreigners and experiencing a new life style appeals to them, therefore they tend to interact with and talk to tourists more often. Particularly young local men and women tourists make friends for sexual reasons (Doğan, 2004: p. 87).

The Opposite Sex - most relationships between younger locals and tourists are motivated by sexual gratification. These kinds of relationships are usually between young local men and female tourists, whereas local women trying to establish a relationship with male tourists usually have an ulterior motive of ostensibly a good marriage (Doğan, 2004: p. 87). Though "sex tourism" has generally been applied to the behaviour of tourists whose purpose is to engage in commercial sex with local women in tourist destinations, it can have a wider application. The term doesn't essentially imply prostitution and can potentially be used to apply to the behaviour of tourists who expect sexual interaction with fellow tourists in resorts, or non-commercial sex with locals in Western destinations as a routine part of their holiday experience (Jeffreys, 2003).

Children - thanks to their curiosity, children are interested in tourists, and they run after them in an attempt to communicate. This could be annoying for some tourists, as others enjoy children's interest (Doğan, 2004: p. 87).

Tourism Professionals - this is the group tourists interact most frequently. Alongside their relations among themselves, tourists most often interact with hotel employees, waiters, sales people, guides and others offering tourism services (Doğan, 2004: p. 88).

As tourists spend a limited amount of time in the holiday location their interaction with the locals are limited. Especially the relations of tourists who lodge in the holiday villages and outside the residential areas are limited to contact with tourism professionals. The likes of tourism professionals are those directly connected to the airport, customs officers, police, drivers, travel agencies, hotel employees, vendors, guides and other related workers (Avcıkurt, 2003: p. 60).

\section{Hospitality as a Tradition of Turkish Society}

Hospitality was a very important value even in the nomadic Turkish society. Sayings of Mahmud Kashgari "Guests come with their blessings" and Dada Gorgud (Dede Korkut) "Better to knock down bad households that receive no guests" are examples of the Turkish mentality towards hospitality. In the nomadic culture hospitality is partially related to benevolence, and benevolence is based on the idea of human's inability to spend more than their share. Turkish society still has a custom of hospitality (Tezcan, 2000). As mentioned in a paper by Şen (2005), two celebrities, Tom Hanks and Vladimir Putin have uttered their surprise in the face of the hospitality of our citizens.

Two countries, Thailand and Turkey, have come to the fore worldwide with their traditions of hospitality which plays an important role in broadcasting their images to the world. Analysis made on the understanding of hospitality in these two countries shows that this traditional structure will survive through the many years into the future (Şen, 2005).

On the other hand, there are many problematic elements in regard to locals' relations with tourists (Kozak, 2007). Although it is possible to experience the taste of traditional hospitality in non-touristy small villages, particularly in the interior of Turkey (Tucker, 2003), there is a sense that this authenticity may disappear in similar towns of the coastal zones and metropolistan cities (Korzay \& Alvarez, 2005). As a consequence of these observations, this study aims to examine the tourist and hospitality notions of young Turkish people.

\section{Methodology}

Qualitative methodology was used in this research. Research was conducted in the city of Izmir which is both a major tourism destination and one of the major metropolitan cities of Turkey. Face to face interview techniques was used to collect data from the students of a foundation university in this city. Simple random sampling technique was used in order to give every student of the university an equal chance to be interviewed. With each respondent an unstructured face to face interview was been conducted. Unstructured interviews allow researchers to focus the respondents' talk on a particular topic of interest, and may allow researchers the opportunity to test out his or her preliminary understanding, while still allowing ample opportunity for new ways of seeing and understanding to develop (Robert Wood Johnson Foundation, 2011).

\section{Descriptive Statistics of the Sample}

In this research interviewers made face to face interviews with 102 students of aforementioned university. The mean age of the students was 21 years old (Table 1) which is very appropriate for the target of this study. Six of the respondents refused to give demographic information. The respondents were divided between 56 percent female and 44 percent male. Respondents claiming to speak foreign languages were 92 percent speaking English as a foreign language, while 6 percent of them spoke German and 2 percent spoke French, beyond Turkish as a mother-tongue. Respondents claiming to have travelled outside of Turkey equalled 45 percent. A total of 58 percent of the respondents claimed work experience in tourism sector and 71 percent claimed an intention to work in tourism sector in the future.

\section{Findings}

\section{Evocations of the Term "Tourist"}

At the beginning for each interview a simple question was asked to the respondents: what are the words that come to your mind when the subject is "tourist"? Table 2 indicates the percentage weight of specific words that came to the respondents'

Table 1.

Descriptive statistics of sample.

\begin{tabular}{llllll}
\hline & $\mathrm{N}$ & Min. & Max. & Mean & $\begin{array}{l}\text { Std. } \\
\text { Deviation }\end{array}$ \\
\hline Age & 96 & 18 & 27 & 21.22 & 1.848 \\
Sex $(1=$ Female; $2=$ Male) & 102 & 1 & 2 & 1.44 & .499 \\
$\begin{array}{l}\text { Travelled abroad } \\
(1=\text { Yes; } 2=\text { No) }\end{array}$ & 96 & 1 & 2 & 1.55 & .500 \\
$\begin{array}{l}\text { Experience in tourism } \\
\text { sector(1=Yes; No) }\end{array}$ & 96 & 1 & 2 & 1.42 & .496 \\
$\begin{array}{l}\text { Intention to work in tourism } \\
\text { sector }(1=\text { Yes; } 2=\text { No) }\end{array}$ & 94 & 1 & 2 & 1.29 & .455 \\
Valid N (listwise) & 94 & & & & \\
\hline
\end{tabular}


Table 2.

Evocations of the term "tourist".

\begin{tabular}{ll}
\hline Words & Percent \\
\hline Money (to be gained by the local people) & $43 \%$ \\
Entertainment (opportunity for the respondent to share with) & $41 \%$ \\
Foreigner (different culture) & $21 \%$ \\
Culture (opportunity to learn about) & $20 \%$ \\
Hotel & $15 \%$ \\
Guest & $14 \%$ \\
Sex & $5 \%$ \\
\hline
\end{tabular}

minds when subject was "tourist". Respondents claiming that the word "tourist" evokes money as the earnings of local people equalled 43 percent. Following closely, 41 percent of respondents have said that the evocation of word "tourist" is entertainment which means they might get the opportunity to share it with tourists. A total of 21 percent of the respondents claimed that the word "tourist" associates with foreigner who comes from a different country and culture, while 20 percent claimed culture which contains the hope of learning about those cultures. A total of 15 percent of the respondents have stated that word "tourist" evokes hotel, while 14 percent claimed guest and 5 percent claimed sex. These numbers point out that the majority of current research participants perceive tourists as the source of economical and social benefits more than they see the tourists as guests.

\section{Feelings and Thoughts about "Tourists"}

Another open ended question of this research was related to the respondents' feelings and thoughts about tourists. Findings expose that most of these young Turkish people have positive feelings and attitudes towards tourists, as can be gained from selected sentences from the interviews (below).

Interviewer: "Can you express any of your 'inner thoughts' of how you feel about foreign tourists here?"

20 year old, male, Computer Programming student: "I am proud of that the tourists wonder about my country and they visit it."

22 year old, male, Industrial Engineering student: "I believe that it is necessary to respect tourists a little more in our country. There are a lot of tourists feeling harassed outside their hotels, so they choose to stay in the borders of accommodation facilities."

20 year old, female, Public Relations student: "In the era that tourism sector keeps growing, it is important to respect tourists. Every single tourist that we interact culturally adds something to us."

20 year old, female, Computer Engineering student: “Tourists are special guests in our country. We should introduce our history, culture, food and all the other unique characteristics to them. People should try to understand tourists and not misbehave."

As it was specified in preceding paragraphs, hospitality is one of the cornerstones of Turkish culture. Majority of Turkish people feel bound to honor guests in the best possible manner and try strongly to communicate that (enjoyturkey.com, 2011). Hazel Tucker stated that the people of Goreme, a central Anatolian town in the region of Cappadocia, take pride in present- ing a culture of warm hospitality. The concepts of hospitality to encourage guests are central to the villagers' discourses regarding themselves, their lives and tourism. Traditional hospitality concept is associated with pride which is another significant characteristic of Turkish people and guests to any Turkish village must be treated with the utmost respect and generosity (Tucker, 2003: p. 122).

20 year old, female, Tourism Management student: "Tourists are people who would like to be distant from the place they live for a certain period of time, and would simply like to have a good time, to relax or to rest. Because they pay in return for the services provided, they always expect more and more... Unfortunately, some tourists behave as if they had purchased the personnel of the accommodation, catering, entertainment or other facilities, as well. Such an approach can really make you lose your patience."

"Pride" having vital importance is another inherent feature of Turkish society. They are sensitive to the concept of "Respect" as the respondents stated above. When they realize that particular tourists misbehave or behave disrespectfully, their reaction could be stiff because such attitudes would be perceived as undignified. The tourists' position as guests in relation to locals' hospitality can be confusing for both players. Situations often arise in which tourists feel confused about offers of generosity and friendship in the tourism realm, or where they feel trapped and restricted by the obligatory ties created by their hosts. Similarly, the locals increasingly feel that their hospitality is abused and eroded by tourists (Tucker, 2003: p. 135).

22 year old, male, Business Administration student: "When tourist and tourism is the discussion subject, I directly think about their contribution to the national economy. In order to increase their contribution, tourists' needs and wants should be satisfied in the best possible way. Besides, our people should be trained and public awareness of tourism and the tourist must be raised."

\section{Conclusion}

Tourism industry is established on a web of interactions between locals, providers, tourism services, the tourist, and the natural environment (Kozak, 2006). This kind of interactionweb is usually denser between younger locals and tourists, so it becomes obvious that their attitude toward the word "tourist" has a vital importance. This study seeks an insight whether young Turkish people sustain the notion of traditional "Turkish Hospitality" by seeking inputs based on their perceptions of tourists.

Although the Turkish university students participated in this research considered tourists as a source of income, they also regarded tourists as fun-loving people coming from foreign countries and different cultures, recognising they stay in hotels as valuable, paying guests for a period of time. The occurrence of the word "Guest" was less frequent than expected: in the light of traditional Turkish Hospitality and family structure it was anticipated that respondents would see tourists as guests in the first place. However, it is pleasing to observe that "Hospitality" and "Guest" notions haven't been entirely faded away.

The issue of hospitality has long been important to the Turkish psyche and sense of identity: it has been deeply rooted in Turkish culture and has survived throughout history. Turkey, as a macro tourism destination, should take all the precautions necessary in order to turn this inestimable quality of Turkish 
culture into an advantage for local tourism - while at the same time preserving the innate and spontaneous character of this intensely local hospitality. Local people at the destinations, employees of all the businesses connected with tourism sector and tourism students should be educated/trained so as not to ignore this aspect of Turkish culture. This level of apparently natural warmth-of-hospitality is not so common in other places around the world, and it could be argued that the Turkish community could cherish and empower such hospitality for later generations.

\section{Limitations of the Study and Suggestions for Future Research}

The generalised character of current research findings has been necessary because of the limited qualitative nature of related research. Even so, it can be claimed that some distinctive findings were obtained. Researchers should enlarge the sample size for future studies. The qualitative nature of current study might be seen as another limitation of the research. Use of quantitative methods could be suggested for future research. Another issue that could be addressed in future research is the relation between "commercial provision of services in tourism realm" and "pride" concept which is one of the significant characteristics of Turkish society.

\section{REFERENCES}

Avcikurt, C. (2003). Turizm Sosyolojisi turist-Yerel Halk Etkileşimi. Ankara: Detay Yayıncilik.

Butler, R. W. (1980). The concept of a tourist area cycle of evolution: implications for management of resources. Canadian Geographer, 24, 5-12. doi:10.1111/j.1541-0064.1980.tb00970.x

Cohen, E. (1984). The sociology of tourism: Approaches, issues and findings. Annual Review of Sociology, 10, 373-392.

doi:10.1146/annurev.so.10.080184.002105

Cooper, C., Fletcher, J., Fyall, A., Gilbert, D., \& Wanhill, S. (2008). Tourism Principles and Practice (4th ed.). Harlow: Pearson Education Limited.

De Kadt, E. (Ed.) (1979). Tourism: Passport to development? New York: Oxford University Press.

Doğan, H. Z. (2004). Turizmin sosyo-kültürel temelleri. Ankara: Detay Anatolia Akademik Yayincılik.

Doxey, G. V. (1975). When enough's enough: The natives are restless in Old Niagara. Heritage Canada, 2, 26-27.

Enjoy Turkey. (2011). People, folklore, culture: People and mentality. URL (last checked 23 November 2011).

http://www.enjoyturkey.com/info/culture/people_folklore.htm

Jeffreys, S. (2003). Sex tourism: do women do it too? Leisure Studies, 22, 223-238. doi:10.1080/026143603200075452

Korzay, M., \& Alvarez, M. (2005). Satisfaction and dissatisfaction of Japanese tourists in Turkey. Anatolia, 16, 176-193. doi: $10.1080 / 13032917.2005 .9687176$

Kozak, M. (2007). Tourist harrassment: A marketing perspective, $A n-$ nals of Tourism Research, 34, 384-399.

Kozak, N. (2006). Turizmin Toplumsal Yönleri, Turizm Gazetesi. URL (last checked 1 March 2011). http://www.turizmgazetesi.com

Robert Wood Johnson Foundation. (2011). Qualitative Research Guidelines Project, Unstructured Interviews. URL (last checked 28 November 2011). http://www.qualres.org/HomeUnst-3630.html

Şen, N. (2005). Rekabet Avantajlarimiz, Turizm Gazetesi. URL (last checked 25 October 2011). http://www.turizmgazetesi.com/articles/article.aspx?id=19720

TC. Kültür ve Turizm Bakanlığı (2011). Turizm Verileri. URL (last checked 28 September 2011). http://www.kultur.gov.tr/TR/dosya/1-279999/h/turizmverileri.pdf

Tezcan, M. (2000). Türk Ailesi Antropolojisi. Baski, Ankara: Imge Kitabevi Yayınlari.

Tucker, H. (2003). Living with tourism: Negotiating identities in a Turkish village. London: Routlage Taylor \& Francis Group. 